\title{
THE ESSENTIALITY OF CONSIDERING THE KANTIAN THEORY OF AUTONOMY BY ISLAMIC EDUCATION
}

\section{Javad Fakhkhar Toosi*, Asyraf Isyraqi Jamil*\#, Mohd Yakub@Zulkifli Mohd Yusoff**}

*Islamic Education Programme. Academy of Islamic Studies. University of Malaya. 50603. Kuala Lumpur. Malaysia.

**Department of al-Quran \& al-Hadith. Academy of Islamic Studies. University of Malaya. 50603. Kuala Lumpur. Malaysia.

Email: *\#isyraqi@um.edu.my

DOI: https://doi.org/10.22452/afkar.vol21no1.5

\begin{abstract}
Khulasah
Makalah ini mencari penyelesaian terhadap salah satu masalah dalam pendidikan Islam iaitu keperluannya memberi perhatian kepada Teori Autonomi Kant atau kebebasan moral. Merujuk kepada pandangan para ilmuan, autonomi merupakan simbol pendidikan moden, dan makalah ini bertujuan membincangkan justifikasi perhatian pendidikan Islam terhadap teori tersebut. Kaedah teoretikal dan kajian kualitatif digunakan dalam kajian ini, serta literatur utama berkaitan autonomi dalam pendidikan akan turut diberi perhatian untuk membantu dalam mencapai objektif kajian. Makalah ini akan membuktikan bahawa pendidikan Islam mesti mempertimbangkan kedudukan Teori Autonomi Kant dan mengambil pendirian sama ada ingin menerimanya atau tidak, iaitu dari sudut pandang ilmuan Islam. Pencapaian yang dapat dibuktikan menerusi makalah ini ialah pengesahan bahawa rasional dan kebebasan merupakan dua tonggak utama dalam pendidikan moden, dan pendidikan Islam perlu memberikan ulasan terhadap kedua-duanya. Dari sudut yang lain, Teori Autonomi Kant memperkenalkan tahap tertinggi
\end{abstract}


dalam rasional dan kebebasan yang mampu mengabaikan teori-teori pendidikan yang menyokong tahap yang rendah bagi kedua-dua aspek tersebut jika Teori Autonomi Kant diterima. Justeru, pendidikan Islam perlu memberikan pandangan tersendiri terhadap rasional dan kebebasan yang telah dibincangkan dalam teori sedia ada. Pencapaian lain yang diperolehi menerusi kajian ini ialah pembuktian bahawa penerimaan atau penolakan teori autonomi akan memberi kesan terhadap tujuan dan kaedah dalam pendidikan moral. Oleh itu, pendidikan Islam perlu menjalankan penelitian terhadap teori autonomi ini dan menetapkan pendiriannya terhadap teori tersebut. Makalah ini juga mencadangkan agar lebih perhatian perlu diberikan terhadap perbincangan tentang teori autonomi dari perspektif Islam.

Kata kunci: Autonomi; kebebasan moral; Pendidikan Islam; rasional; kebebasan.

\begin{abstract}
This article seeks to solve one of the problems of Islamic education which is its need for attention to Kant's autonomic theory or moral independence. According to scholars, autonomy is the symbol of modern education, and the current article pursues to illustrate why the Islamic education must pay attention to this theory. The qualitative research method which focuses on the theoretical aspect is used in this study. It employs the primary literatures regarding autonomy in education.. The purpose of this paper is to prove that Islamic education must consider Kant's theory of autonomy and take a stance as to accept it or not, from the Islamic perspective. The article discovers that rationality and freedom are two pillars of modern education, and Islamic education needs to comment on these two pillars. On the other hand, the autonomic theory of Kant, introduces the highest level of rationality and freedom, whose acceptance leads to abandoning the other educational theories that support the lower levels. Therefore, the Islamic education
\end{abstract}


needs to form its own opinion on the concepts of rationality and freedom as they are raised in this theory. The article derives a conclusion that acceptance or rejection of autonomy has a significant impact on the goals and methods of moral education. Thus, Islamic education may need to reflect and open its doors on the goals and methods. To summarize the article; Islamic education needs to further evaluate the theories of autonomy and clarify its position on this theory with regard to eucation. This article suggests more discussion of the theory of autonomy is made in Islamic circles.

Keywords: Autonomy; moral independence; Islamic education; rationality; freedom.

\section{Introduction}

The word autonomy is derived from 'auto' means self, and 'nomus' means the law, both words have Greek origins. Kant calls his theory against 'heteronomy', noting that the will, if not being the sole lawmaker on its own, will be based on a 'heteronomy' and follows rules that are set by others and out of its essence. The reason for using such a word to interpret Kant's theory of moral independence is that the ancient Greeks used 'autonomous' for the people who followed their independent laws. ${ }^{1}$

Kant's autonomy has been raised in the philosophy of ethics. After Kant, the theory found many supporters. It has the highest level and position among ethical theories, and that scholars have counted this theory within the modern ethical views. ${ }^{2}$ Kant's theory of autonomy means that human beings, without being influenced by any external factors, act based on his or her own reason's intuition. ${ }^{3}$

${ }^{1}$ Gerald Dworkin, "The Concept of Autonomy," Grazer Philosophische Studien 12(1981): 203-213.

2 John Reeder, "What Is a Religious Ethic?," The Journal of Religious Ethics Vol. 25, No. 3 (1997): 157-181.

${ }^{3}$ See Hans Agné, "The Autonomy of Globalizing States: Bridging the Gap between Democratic Theory and International Political 
Kant's external factors are any external force outside one's pure judgment of reason. So, the term includes obeying the rules; to obey the parents; to obey the religious orders; to follow the emotions and desires of the soul and so on. In Kant's opinion, only under this condition, the will is free. ${ }^{4}$

The autonomy is based on two main foundations. First: humans' ability to recognize moral values. Second: the freedom of will. Humans' will must be free and not affected by any external factor. According to Kant, if we assume that the freedom is an adjective for something, then it must be the will, and the good will is what makes other things good. ${ }^{5}$ So to interpret his words, it is that the cause is free when no other factor causes it to be necessary. The other is the material external factors as well as internal spiritual factors, such as feelings and impressions arising from these emotions. $^{6}$

Autonomy has an important position in modern education considering the goal of education, namely independence. $^{7}$ In many educational studies, the educational goals and aims are codified in accordance with the human needs expressed in the theory of Maslow. ${ }^{8}$ Here we can point out the important role of Kant's autonomic theory in relation to Maslow's theory. The autonomy offers the greatest degree of moral independence, and although it

Economy," International Political Science Review / Revue internationale de science politique Vol. 32 No. 1 (2011): 43-60; .

${ }^{4}$ Michael Gass, "Kant's Causal Conception of Autonomy," History of Philosophy Quarterly Vol. 11 No. 1 (1994): 53-70.

5 Immanuel Kant, The Critique of Practical Reason, trans. I. Rahmti (Tehran. Iran: Sophia publication, 2016), 76

${ }^{6}$ Ibid.

7 Jānis (John) Tālivaldis. Ozoliņš, "Reclaiming Paedeia in an Age of Crises: Education and the Necessity of Wisdom," Educational Philosophy \& Theory Vol. 47 No. 9 (2015), 870-882.

8 Lloyd Greene and George Burke, "Beyond Self-Actualization," Journal of Health and Human Services Administration Vol. 30 No. 2 (2007): 116-128. 
is only in the context of morality, it is a subset of the need for independence that Maslow has proposed in general. Piage $^{9}$ and Kleberg ${ }^{10}$ consider moral independence as the final stage of moral education. Accordingly, Kant's theory is multi-dimensional relating to this educational goal:

i. Defining and introducing moral independence.

ii. Providing philosophical and epistemological foundations for moral independence as an educational goal.

iii. Deepening the meaning of moral independence.

As a result, we can say the theory of autonomy is of high position in modern education and thus after Kant, other scholars who proposed autonomy, such as Nietzsche, ${ }^{11}$ Piaget, ${ }^{12}$ Rawls ${ }^{13}$ or Kohlberg, ${ }^{14}$ all have been affected by Kant and have retained Kant's original main elements despite minor adjustments or modifications or additions.

In any case, autonomy that can be regarded as an important educational goal has not been seriously taken into consideration in Islamic education. This negligence is due to the fact that, a great number of researchers believe the theory contradicts foundational teachings of Islam. This is while autonomy's acceptance, opens the way to significant

${ }^{9}$ George W. Oesterdiekhoff, "Relevance of Piagetian Cross-Cultural Psychology to the Humanities and Social Sciences," The American Journal of Psychology Vol. 126 No. 4 (2013), 477-492.

${ }^{10}$ Lawrence Kohlberg, The Psychology of Moral Development: The Nature and Validity of Moral Stages, vol. 2, Essays on Moral Development (New York.United States: Harper \& Row, 1984).

11 Ken Gemes and Christopher Janaway, "Nietzsche on Free Will, Autonomy and the Sovereign Individual," Proceedings of the Aristotelian Society, Supplementary Vol. 80 (2006): 321-357.

12 Oesterdiekhoff, "Relevance of Piagetian Cross-Cultural Psychology to the Humanities and Social Sciences," 477-92.

13 Robert S. Taylor, "Kantian Personal Autonomy," Political Theory Vol. 33 No. 5 (2005), 602-28.

${ }^{14}$ Kohlberg, The Psychology of Moral Development, 2. 
changes in the Islamic moral education, and, leads to tremendous changes in educational methods and objectives. These changes will resolve some of the problems claimed in Muslim's moral education. For example, many scholars believe that the weaknesses of the educational systems in Muslim countries are due to ignoring modern educational theories such as autonomy. Weaknesses such as limited capacity for critical thinking, utilising methods like dictation or habituation (which are used extensively -as some scholars have claimed- in Muslim educational systems), the lowering of self-confidence and so on. ${ }^{15}$ While at the same time, opening the way for educational scholars to criticize the Islamic system.

Therefore, if we can study this theory based on the Islamic teachings, we will take an important step towards the development of the Islamic education, as well as resolve many criticisms to Islamic moral education.

\section{Literature Review}

Many works have focused on the relation between autonomy and Islamic education, but most of them have often considered the compatibility or incompatibility of this theory with Islamic teachings. A number of them have considered this theory incompatible, for example:

15 Bradley James Cook, "Islamic Versus Western Conceptions of Education: Reflections on Egypt," International Review of Education / Internationale Zeitschrift Für Erziehungswissenschaft / Revue Internationale de l'Education Vol. 45 No. 3/4 (1999): 339-357. 
Halstead, ${ }^{16}$ Reeder, ${ }^{17}$ Ryan, ${ }^{18}$ Louden, ${ }^{19}$ DiCenso, ${ }^{20}$ and also Elegido, ${ }^{21}$ Rachels, ${ }^{22}$ and Fraenkel ${ }^{23}$ as well as Thibert ${ }^{24}$ and Moad. ${ }^{25}$ As some scholars have advocated for autonomy, they have tried to harmonize it with Islamic principles such as Davids, ${ }^{26}$ Tariq Ramadan, ${ }^{27}$ and Charlene Tan. ${ }^{28}$

16 J. Mark Halstead, "Islamic Values: A Distinctive Framework for Moral Education?," Journal of Moral Education Vol. 36 No. 3 (2007), 283-296; Mohamed Safiullah Munsoor, and Che Zarrina Sa'ari, "Knowledge and Islam on the Non-Rational and Rational-Heart-Brain Inter-Connection: A Classical Islamic Scholarly Perspective." Jurnal Akidah \& Pemikiran Islam Vol. 19 No. 1 (2017), 129-162.

${ }^{17}$ Reeder, "What Is a Religious Ethic?," 157-181.

18 Gillespie Ryan, "Reason, Religion, and Postsecular LiberalDemocratic Epistemology," Philosophy \& Rhetoric Vol. 47 No. 1 (2014), 1-24.

${ }^{19}$ Robert B. Louden, "Kant's Virtue Ethics," Philosophy Vol. 61 No. 238 (1986): 473-89.

${ }^{20}$ James DiCenso, "Kant, Freud, and the Ethical Critique of Religion," International Journal for Philosophy of Religion Vol. 61 No. 3 (2007), 161-79.

${ }^{21}$ Juan Manuel Elegido, Fundamentals of Business Ethics: A Developing Country Perspective (Lagos. Nigeria: Spectrum Books Limited, 1996).

22 James Rachels and Stuart Rachels, The Elements of Moral Philosophy, vol. 119 ( New York: McGraw-Hill, 1993).

${ }^{23}$ Carlos Fraenkel, "Theocracy and Autonomy in Medieval Islamic and Jewish Philosophy," Political Theory Vol. 38 No. 3 (2010): 340-366.

24 Jeffrey Ryan Thibert, "Worldview Education: A Possibility for Autonomy-Facilitating Education in Islamic Schools" (Ph.D., University of Illinois at Urbana-Champaign, 2012).

${ }^{25}$ Edward Omar Moad, "A Path to the Oasis: Sharī 'Ah and Reason in Islamic Moral Epistemology," International Journal for Philosophy of Religion Vol. 62 No. 3 (2007): 135-148.

26 Nuraan Davids and Yusef Waghid, "The Qurān and Individual Autonomy," in Ethical Dimensions of Muslim Education (London: Palgrave Macmillan, Cham, 2016), 69-83.

27 Tariq Ramadan, Radical Reform: Islamic Ethics and Liberation (Oxford.United Kingdom: Oxford University Press, 2009).

${ }^{28}$ Caroline Tan, "Rationality and Autonomy from the Enlightenment and Islamic Perspectives," Journal of Beliefs \& Values Vol. 35 No. 3 (2014), 327-39. 
It is noteworthy that, before we examine autonomy from the Islamic point of view and its adaptation or incompatibility with Islamic teachings we have to prove the use of autonomy in Islamic education, indispensable. If the use of this theory does not bring about any meaning or effect on Islamic education, it is futile to talk about what the Islamic stance is.

However, regarding the impacts of autonomy in the field of Islamic education, some works have been done, but these works discussed those results as the normal results of autonomy without discussing the necessity of entering autonomy in Islamic education. The most significant works that can be mentioned in this regard are Pike $^{29}$, Piper $^{30}$ Erdelack $^{31}$, Kalinsky ${ }^{32}$, Riddet ${ }^{33}$, Hasselberger ${ }^{34}$ and Rasch. ${ }^{35}$

The main difference between the current article and previous works is that, in the current article, the need for bringing autonomy in Islamic education sphere has been thoroughly discussed. This discussion provides a basis for addressing the position of Islam regarding this theory. As it

${ }^{29}$ Mark A. Pike, "Religious Freedom and Rendering to Caesar: Reading Democratic and Faith-Based Values in Curriculum, Pedagogy and Policy," Oxford Review of Education Vol. 35, No. 2 (2009): 133-146.

${ }^{30}$ Laurence Piper, "From Religious Transcendence to Political Utopia: The Legacy of Richard Turner for Post-Apartheid Political Thought," Theoria: A Journal of Social and Political Theory Vol. 57 No. 123 (2010): 77-98.

${ }^{31}$ Wesley Lyons Erdelack, "“A Law Unto Themselves”: Religion and Autonomy in Modern Moral Thought" (Ph.D., Harvard University, 2010).

32 Joseph Mordechai Kalinsky, "The Role of Autonomy within Religious Struggle" (Ph.D., Yeshiva University, 2016).

33 Matthew Riddett, "Education and the Right to Autonomy" (M.A., University of Victoria, 2012).

${ }^{34}$ William Hasselberger, "The Ideals of Agency: Autonomy, Sociality, Individuality" (Ph.D., University of Virginia, 2012).

${ }^{35}$ William Rasch, "Enlightenment as Religion," New German Critique, No. 108 (2009), 109-131. 
prepares the grounds for studying the results and effects of this theory in Islamic education.

\section{Findings and Discussion}

The main question in this study is that: why does the Islamic education have to take into account the theory of autonomy? When answering this question, we will propose two specific factors for the need of Islamic education to consider the autonomy.

\section{i. The Position of Autonomy in the Modern Education}

The theory of autonomy is based on two fundamental principles. 1 . The observance of the law of reason; 2 . The freedom of the will. In fact, it can be said that in this theory, the rationality and freedom are the criterion of morality for human deeds.

Rationality and freedom are the most fundamental foundations of modern education. ${ }^{36}$ Thus for all the educational theories presented in the era of modernity, these two elements are considered as the fundamental basis. ${ }^{37}$ Of course, different interpretations and different levels of the two have been presented in accordance with distinct educational theories, nevertheless, the two elements are considered to be the foundations of modern education..$^{38}$

This said, when looking at the subject from the perspective of Islamic education, we find that Islamic education cannot be indifferent towards the two main principles of modern education, and it is imperative to

36 Ryan Bevan, "Expanding Rationality: The Relation between Epistemic Virtue and Critical Thinking," Educational Theory 59, no. 2 (2009): 167-79.

37 Mohamed Safiullah \& Che Zarrina. "The Soul (Heart) and its Attributes," 93-134.

${ }^{38}$ Ibid. . 
comment on them. ${ }^{39}$ Without commenting on these, the possibility of dialogue between Islamic education and modern education won't be available. ${ }^{40}$

Here we do not insist that Islam accepts these two foundations in the same way as the West and the modern educational context does. We only persist that Islam should take a stance towards these two elements. Modern education is a phenomenon that is based on these two elements, and Muslim scholars should provide the extracted information and correct view about the phenomena regarding their religious sources.

This is where the second question arises, why should these two elements (rationality and freedom) be considered in the context of Kantian theory of autonomy? This is despite the fact that modern education schools provide different levels of these two. Kant's theory of autonomy, has a unique feature, namely, in this theory the highest level of rationality and freedom is presented, in such a way that all the other interpretations of the two factors are lower than the rationality and liberty of the Kantian theory. In the idea of moral independence, which requires a particular educational system, the interpretation of Kant is considered to be the central point. Thus, after him, other scholars who have proposed autonomy, such as Nietzsche, ${ }^{41}$ Piaget, ${ }^{42}$ Rawls, ${ }^{43}$ or Kohlberg, ${ }^{44}$ have all been influenced by Kant and retained the main original elements of Kant's.

39 Linda Herrera, "Education, Islam, and Modernity: Beyond Westernization and Centralization", Comparative Education Review Vol. 48 No. 3 (2004), 318-326.

${ }^{40}$ Ibid.

41 Gemes and Janaway, "Nietzsche on Free Will, Autonomy and the Sovereign Individual," 321-357.

42 Oesterdiekhoff, "Relevance of Piagetian Cross-Cultural Psychology," 477-492.

43 Taylor, "Kantian Personal Autonomy," 602-628.

44 Kohlberg, The Psychology of Moral Development: The Nature and Validity of Moral Stages 2, 234. 
It is clear that, rejecting this theory from the Islamic point of view does not mean rejecting rationality and freedom at all levels, as it does not mean rejecting other modern educational theories that are based on the two elements. But it gets interesting from the point where Islam accepts the autonomy of Kant. The acceptance of the highest interpretation of the rationality and freedom that has been proposed in the Kantian theory coerces the moral education to determine the highest level of these two elements as a goal of education, then moral education targets the lower levels of the two, or uses methods, that lead to lower levels of rationality and freedom, which should be abandoned. Accepting the lower levels, will only be possible if these levels considered as the early stages and phases of achieving the higher and the highest, are reaching towards autonomy.

In other words, education systems that lead to lower levels of rationality and freedom, lose their authenticity and will only be recognized as the sub-objective of the final goal, namely autonomy. In other words, autonomy's acceptance makes this title (autonomy) as the goal of moral education determined and this point (regardless of any other consequences) is itself a great transformation and a profound revolution in moral education.

One would ask why Islam should take a stance towards the elements of modern education, namely, rationality and freedom. The answer to this question is very clear. Islam is the complete and comprehensive religion of Allah; a religion that was sent not only to people of a certain age and one generation, but to all human beings to the day of resurrection. For this reason, Islam cannot be indifferent towards the changes that occur in human life in different ways. As it cannot be different to the achievements of human knowledge, gained throughout centuries. That is why, Islam as the ultimate and final religion of the Lord, must express his position in the context of new phenomena 
that are effective in human life. Islam has to clarify the duty of its followers. So, modern education based on rationality and freedom is one of the new phenomena that is a human achievement, then Islam must clarify its views on these phenomena.

The importance of this assessment becomes clearer when we see that some scholars have criticized the Islamic education for what they consider to be incompatible with rationality and freedom of the will. For example according to Elegido ${ }^{45}$ ethics is a mission to live well, and also is understanding of the method for realizing this goal (living well). He considers the religious ethical systems for example Islam, to be entirely based on a theoretical perspective. According to this view, the moral values cannot be understood without theoretical foundations and views and its immediate consequence is that the rationality and freedom of the will won't be considered in Islamic education; since these two do not recognize the theoretical foundations in moral values.

Rachels believes that in Islam, ethics is understandable only in the realm of religion, and in other words, there is no meaning of morality outside religion. ${ }^{46}$ As well as Aidaros who wrote: "Deontology theory is also not acceptable in an Islamic context because the only lawgiver for the overall system, including the ethical system, is Allah". ${ }^{47}$

Fraenkel states the incompatibility of Islam with rationality and freedom more explicitly. ${ }^{48}$ Based on his view, according to the majority of scholars, despite the

${ }^{45}$ Elegido, Fundamentals of Business Ethics, 84.

${ }^{46}$ Rachels and Rachels, The Elements of Moral Philosophy, 119.

47 A.-H. Al-Aidaros, Shamsudin, F. M., \& Idris, K. M., "Ethics and Ethical Theories from an Islamic Perspective," International Journal of Islamic Thought Vol. 4 (2013): 5; Zakaria, Idris, "Ibn Sina on the Benefits of Worship to the Masses," Jurnal Akidah \& Pemikiran Islam Vol. 15 No. 1 (2014), 115-134.

${ }^{48}$ Fraenkel, "Theocracy and Autonomy in Medieval Islamic and Jewish Philosophy," 340-366. 
differences in the interpretation of the rationality, Islam will not be compatible with freedom of the will and following human reason at any level. The reason, according to him is that, based on rationality, God is not the legislator, but we are the ones who regulate it. This is also the point that has been repeated in the words of Halstead when he said Islamic ethics does not rely on experience and human

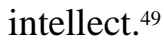

If we want to continue to provide evidence in this regard, we can point to Thibert. ${ }^{50}$ According to him, in Islam, the concept of the good life is met by submission to the will of God, and for this reason, the goal of Islamic education is to reach the point of submission to the divine will. While, rationality asserts that everyone must seek out the resources of good life within themselves, in Islamic education, based on its goal which is submission; we must seek and obtain the resources of good life from the Islamic traditions, the Qur'an, and the prophet's narratives. In the system of rationality, a lifestyle which is not a product of a process of reason, is not confirmed as the ideal lifestyle. The good life is the product of the critical view and the choice of autonomy among multiple options. ${ }^{51}$

The incompatibility of Islam with rationality and freedom in another way has also been emphasized by another group of scholars. They have proposed that the Islamic moral system is known to be related to a special legal system called Shariah. The law determines moral boundaries. The basis of Islamic ethics in the system of Shariah contributes to the incompatibility of rationality with Islamic teachings. For example, Carney believes, the presupposition of a discussion about the ethical system of each religion should be based on the existence of such a

49 Halstead, "Islamic Values: A Distinctive Framework for Moral Education?," 283-296.

50 Thibert, "Worldview Education," 87.

${ }^{51}$ Ibid., 68. 
special system,,$^{52}$ or Strauss claims that the legality and the connection to Shariah distinguishes not only in the ethical system of Islam, but also in general.

Same goes to the other Abrahamic religions, namely, Judaism. In these religions, while reliance on reason is accepted, but the origin of the 'Jerusalem Reason' is the fear of God that leads the person to obey him. In these religions, subjection to God is the central point. While not only in the rationalism, but in the Athenian ethos this reason that directs the rationality of mankind. ${ }^{53}$ Schneewind like Strauss and Carney, believes that Islamic morality is based on 'obedience', while the core of the rationality rests on 'self-reliance'. ${ }^{4}$ Accordingly, when the issue is 'obedience', we owe to the Lord and therefore, without knowing the cause and the reason of what we do as ethics, we carry them out as our duties from God, the promise of the reward of paradise and the threat of the punishment of hell is the guarantor of the implementation of these assignments. ${ }^{55}$ Halstead should also be added to this group of researchers the statement: "Knowing the reason for doing good things and the reason for the need to leave bad things in the moral education of Islam is less important". ${ }^{56}$

We do not want to mention all the criticisms to Islamic education from the perspective of rationality and freedom, as we do not want to admit to these criticisms and support them. The examples have been mentioned to point out that,

${ }^{52}$ F. Carney, " Some Aspects of Islamic Ethics," The Journal of Religion Vol. 63 No. 2 (1983), 159-174.

${ }^{53}$ L. Strauss, Jerusalem and Athens: Jewish Philosophy and the Crisis of Modernity (New York: State University of New York Press, 1997), 377-405.

54 J. B. Schneewind, The Invention of Autonomy: A History of Modern Moral Philosophy (Cambridge: Cambridge University Press, 1999), 4.

55 Ibid.

56 Halstead, "Islamic Values: A Distinctive Framework for Moral Education?," 283-296. 
assessing this issue and showing the Islamic point of view on the two pillars of modern education, i.e., rationality and freedom is a necessary and unavoidable fact.

So far, we have shown the need for Islamic education to consider the Kantian theory of autonomy in terms of the nature and the identity of the theory and its position in the modern education. Thus, we shall take this point from another perspective; from the perspective of the effects and consequences of the theory's acceptance in the field of moral education.

\section{ii. The Consequences of Autonomy in Islamic Education}

Autonomous ethical education has distinct differences with the other moral educational systems. These differences are particularly marked in terms of educational methods and objectives. That is why the theory of autonomy was taken very seriously by the scholars after Kant's presentation.

Islam needs to explain its stance on educational methods that will get altered due to the acceptance of autonomy. In the context of methods and objectives, it must first be clarified whether these changes are accepted by Islam or not. For example, when we talk about the necessity of abandoning habituation as a method of moral education, we should know the position of Islam regarding this educational method and what is the opinion of Islam about the alternatives to this method of education. Therefore, the same reason justifying the theoretical discussion of the theory of autonomy, also justifies the theoretical discussion of the effects and the results of this theory.

\section{a. Consequences in Objectives}

Islamic moral education has a final purpose, which is extracted from the Qur'an and the Sunnah that can be said to be human beings are adorned with virtues and good ethics as well as avoiding evil and vices. To achieve this ultimate goal, a set of sub-goals and phases are considered. The sub goals are the stages that have to be passed in order 
to achieve the ultimate goal step by step. We call these sub goals: objectives.

Acceptance of autonomy affects the sub-goals of the Islamic moral education. The importance of the role of the sub-objectives (phases) in moral education is undeniable; because based on these goals the educational methods are regulated and therefore, we will see that some of the common methods should be replaced by other ones.

The first change regarding the sub-objectives of Islamic moral education is 'releasing the will'. To release from motivation, means freeing the will from any external motive that transcends essence of the moral act. Reaching this point needs consideration of training of the mystic person (al-'árif), as the objective of Islamic moral education.

The second change in field of objectives is 'reaching the stage of legislation of reason'. With the first element of autonomy (following the law of reason) we consider the issue of the legislation of the reason and its characteristics. Based on this element of autonomy's, ethical education should be designed in such a way that elevates the person to the point of legislation of reason.

\section{b. Consequences in Methods}

The effects of the acceptance of theory of autonomy on moral education will not be specific to objectives, but in the field of methods, we will also face these effects. The effects of the acceptance of theory of autonomy on moral education will not be specific to objectives, but in the field of methods, we will also face these effects.

The educational methods used by educational policy makers and administrators to transfer values and educational content to learners and guide them to the objectives, have the instrumental role in conveying of the values and content. The determination and the selection of methods is based on the role they play in transferring and the delivery process. Therefore, any method that plays a 
more vigorous role in this process has to be taken into account. ${ }^{57}$

When it comes to methods, we need to consider the milieu, psychological, natural, inheritance and other benefactors. In order to determine the methods, nowadays, scholars do extensive studies. Therefore the nature of the discussion of educational methods is scientific, and the various developments and changes that go on within human societies over time are effective in these ways. The first change in the field of method is appear by 'eliminating the habituation method'.

One of the methods emphasized by Islamic moral education is the use of habituation i.e people try to get used to good behaviour and good manner. In such a way that they behave normally and without the need for thought and decision. Achieving moral steady states malakah, is done using the normalization and habituation methods. Habit is an automated, orderly and coordinated relation among all spiritual activities of the individual. ${ }^{58}$ To repeat numerous actions in close proximity is another definition. ${ }^{59}$ They believe that encouraging someone to accept getting used to a habit, in such a way that it regulates his behaviour in the long run. ${ }^{60}$ One can also define habituation as 'learning the excellences of character through engaging in virtuous behaviour and avoiding non-virtuous behaviours.' ${ }^{61}$

57 Muhammad Naquīb al-Attās, Aims and Objectives of Islamic Education, (World Conference on Muslim Education) (London: Hodder and Stoughton, 1979), 76.

${ }^{58}$ L. Singh, Fu, C. L., et al., "Back to Basics: A Bilingual Advantage in Infant Visual Habituation," Child Development Vol. 86 No. 1 (2015). 87-105.

${ }^{59}$ Ibid.

${ }^{60}$ J. Kerr, "Habituation: A Method for Cultivating Starting Points in the Ethical Life," Journal of Philosophy of Education Vol. 45 No. 4 (2011), 34-52.

${ }^{61}$ Ibid. 
According to Aristotle, the habit, not only simplifies action and eliminates the suffering of effort, but also inclines it. ${ }^{62}$ In his view, repetition produce habits and habits produce inclination, and desire, in turn, gives rise to action. The result of this is a kind of knowledge. ${ }^{63}$ Aristotle's statement shows his view in this regard, which he says in the essay of Nicomachean Ethics.

Virtue cannot be found except through habit. Our nature has given us several talents. We convert these talents as a steady state through the use of them and their continued usage. Because nobody can do anything good unless he continually does it. The most importance belongs to the habit; so one needs to get used to good behaviour from the beginning of a childhood. Because virtue is divided into rational and ethical, and rational virtue is acquired through learning and therefore requires experience and time. But moral virtue comes from the way of habit and nature. ${ }^{64}$

Muslim thinkers influenced by the Aristotelian tradition, chose habituation as the most important form of education. ${ }^{65}$ Al-Ghazzāli says:

"Anyone who does good, makes good manners in him, and the a person becomes accustomed to his habits, for example a child is afraid of school at the beginning, and he runs away, but after he is forced to go to school for a while, he will be interested in it by his obligation." 66

${ }^{62}$ Singh et al., "Back to Basics: A Bilingual Advantage in Infant Visual Habituation," 294-302.

63 Kerr, "Habituation: A Method for Cultivating Starting Points in the Ethical Life," 643-55.

64 Aristotle, Nicomachean Ethics, trans. A. Lotfì Sayyid, vol. 1 (Cairo: Dār al-Kutub al-Mișrīyyah, 1963), 27.

65 Syed Muhammad Naquib al-Attas, Islam and the Challenge of Modernity: The Search for Islamic Authenticity (Kuala Lumpur: International Institute of Islamic Thought and Civilization, 1996), 44.

66 Al-Ghazālī, Kìmīyā E Saādat (Tehran: Scientific \& Cultural Publication, 1985), 433. 
And elsewhere he says:

"The good ethics have three causes: one is the principle of nature, and it is the grant and grace of God, he creates someone's good luck and humbles him in his own way, the second is to do good things so that they make him accustomed. The third is to surround oneself with good people so that their behaviour affects one." ${ }^{67}$

We can say that according to al-Ghazzāli, the moral education is equal with habituation. Al-Ghazzāli classifies habits, according to the sphere of influence, and divides it into four parts: physical habits (like habit of eating, wearing, playing, etc.); rational habits (like religious and jurisprudential insights and attitudes); conscientious habits (related to human emotions); and moral habits (piety, patience, moderation, courage, etc.). ${ }^{68} \mathrm{He}$ considers the stages of habit formation in two stages of 'creation' and 'stability'. The creational stage is a stage in which human behaviour is not easy and psychologically performed, but with tolerance and difficulty. The stage of stability is such that behaviour and actions become practical and easy. ${ }^{69}$

Another method that has to be changed consequent to the acceptance of autonomy is the coercion method, which should not be used in moral education. Therefore, we are confronted with the question of what will be the fate of this method in Islamic education. How can this educational method be justified based on Islamic teachings? Of course, once again, we repeat that, by abandoning these educational methods, alternative educational methods- based on the theory of autonomy - should be introduced and extracted from Islamic sources (Quran and Sunnah). We will replace

\footnotetext{
${ }^{67}$ Ibid., 434.

${ }^{68}$ Ibid.

${ }^{69}$ Ibid.
} 
the methods after the respective discussion that need to be removed.

Corporal punishment is the third method of education that some scholars have suggested, based on some verses and narratives. It has to be changed based on the theory of autonomy. No punishment exists in the field of education at all. This is a method that is considered in the field of law and legality and is not the responsibility of the mentor.

Another educational method that some researchers recommend is imitation. This method is based on certain traditions and verses. It has also been changed, since the imitation desired by Islam, means referring to the scholars only in case of religious affairs, not blindly following for moral education.

In other words, Islam invites people to follow knowledge (people who do not have knowledge). Not to follow the others in absolute terms. The pursuit of knowledge (for those who lack knowledge in the subject matter) is the command of reason; hence Islam is precisely in line with autonomy. Therefore, we reject imitation as a training method.

\section{Conclusion}

In summary, it can be said that, Islamic education has to consider a serious study of Kant's autonomy for two reasons; the first one is the two elements of the theory, namely, rationality and freedom, which are the foundations of modern education. Islam should comment on the modern education as a phenomenon and clarify the duty of its followers in this regard.

The second reason being that the acceptance of this theory has several effects in the objectives area, and the methods of moral education (which is one of the issues of Islamic education). The autonomous system is different in these two areas with other educational systems, and Islam cannot ignore these differences. 


\section{References}

Agné, Hans, "The Autonomy of Globalizing States: Bridging the Gap between Democratic Theory and International Political Economy," International Political Science Review / Revue internationale de science politique Vol. 32 No. 1 (2011): 43-60.

Al-Ghazzālī, Abū Hāmid Muḥammad bin Muḥammad. Kìmīyā E Saādat. Tehran: Scientific and Cultural Publication, 1985.

Al-Aidaros, A. H., Shamsudin, F. M., \& Idris, K. M., "Ethics and Ethical Theories from an Islamic Perspective," International Journal of Islamic Thought, Vol. 4 (2013): 1-13.

Al-Attas, Syed Muhammad Naquib. Aims and Objectives of Islamic Education (World Conference on Muslim Education). London: Hodder and Stoughton, 1979.

Al-Attas, Syed Muhammad Naquib. Islam and the Challenge of Modernity: The Search for Islamic Authenticity. Kuala Lumpur: International Institute of Islamic Thought and Civilization, 1996.

Aristotle. Nicomachean Ethics, translated by A. Lotfi Sayyid. Cairo: Dār al-Kutub al-Mișrīyyah, 1963.

Bevan, Ryan, "Expanding Rationality: The Relation between Epistemic Virtue and Critical Thinking," Educational Theory Vol. 59 No. 2 (2009): 167-179.

Carney, F., "Some Aspects of Islamic Ethics," The Journal of Religion Vol. 63 No. 2 (1983): 159-174.

Cook, Bradley James, "Islamic Versus Western Conceptions of Education: Reflections on Egypt," International Review of Education / Internationale Zeitschrift Für Erziehungswissenschaft / Revue Internationale de l'Education Vol. 45 No. 3/4 (1999): 339-357.

Davids, Nuraan and Waghid, Yusef. "The Qurān and Individual Autonomy." In Ethical Dimensions of Muslim Education. London: Palgrave Macmillan, 2016: 69-83. 
DiCenso, James, "Kant, Freud, and the Ethical Critique of Religion," International Journal for Philosophy of Religion Vol. 61 No. 3 (2007): 161-179.

Dworkin, Gerald, "The Concept of Autonomy," Grazer Philosophische Studien Vol. 12 (1981): 203-213.

Elegido, Juan Manuel. Fundamentals of Business Ethics: A Developing Country Perspective. Lagos: Spectrum Books Limited, 1996.

Erdelack, Wesley Lyons. "“A Law unto Themselves": Religion and Autonomy in Modern Moral Thought." Ph.D., Harvard University, 2010.

Fraenkel, Carlos, "Theocracy and Autonomy in Medieval Islamic and Jewish Philosophy," Political Theory Vol. 38 No. 3 (2010): 340-366.

Gass, Michael, "Kant's Causal Conception of Autonomy," History of Philosophy Quarterly Vol. 11 No. 1 (1994): 53-70.

Gemes, Ken and Christopher Janaway, "Nietzsche on Free Will, Autonomy and the Sovereign Individual," Proceedings of the Aristotelian Society Supplementary Volumes 80 (2006): 321-357.

Greene, Lloyd and Burke, George, "Beyond SelfActualization," Journal of Health and Human Services Administration Vol. 30 No. 2 (2007): 116-128.

Halstead, J. Mark. "Islamic Values: A Distinctive Framework for Moral Education?", Journal of Moral Education Vol. 36 No. 3 (2007): 283-296.

Hasselberger, William. "The Ideals of Agency: Autonomy, Sociality, Individuality." Ph.D, University of Virginia, 2012.

Kalinsky, Joseph Mordechai. "The Role of Autonomy within Religious Struggle." Ph.D, Yeshiva University, 2016.

Kant, Immanuel. The Critique of Practical Reason, translated by I. Rahmti. Tehran: Sophia Publication, 2016. 
Kerr, J., "Habituation: A Method for Cultivating Starting Points in the Ethical Life," Journal of Philosophy of Education Vol. 45 No. 4 (2011): 643-655.

Kohlberg, Lawrence. The Psychology of Moral Development: The Nature and Validity of Moral Stages Essays on Moral Development, vol. 2. New York: Harper \& Row, 1984.

Louden, Robert B., "Kant's Virtue Ethics," Philosophy Vol. 61 No. 238 (1986): 473-489.

Moad, Edward Omar, "A Path to the Oasis: Sharī 'ah and Reason in Islamic Moral Epistemology," International Journal for Philosophy of Religion Vol. 62 No. 3 (2007): 135-148.

Oesterdiekhoff, George W., "Relevance of Piagetian CrossCultural Psychology to the Humanities and Social Sciences," The American Journal of Psychology Vol. 126 No. 4 (2013): 477-492.

Ozoliņš, Jānis (John) Tālivaldis, "Reclaiming Paedeia in an Age of Crises: Education and the Necessity of Wisdom," Educational Philosophy \& Theory Vol. 47 No. 9 (2015): 870-882.

Pike, Mark A., "Religious Freedom and Rendering to Caesar: Reading Democratic and Faith-Based Values in Curriculum, Pedagogy and Policy," Oxford Review of Education Vol. 35 No. 2 (2009): 133-146.

Piper, Laurence, "From Religious Transcendence to Political Utopia: The Legacy of Richard Turner for PostApartheid Political Thought," Theoria: A Journal of Social and Political Theory Vol. 57 No. 123 (2010): 7798.

Rachels, James and Rachels, Stuart. The Elements of Moral Philosophy, vol. 119. New York: McGraw-Hill, 1993.

Ramadan, Tariq. Radical Reform: Islamic Ethics and Liberation. Oxford: Oxford University Press, 2009.

Rasch, William, "Enlightenment as Religion," New German Critique No. 108 (2009): 109-131. 
Reeder, John P., "What Is a Religious Ethic?," The Journal of Religious Ethics Vol. 25 No. 3 (1997): 157-181.

Riddett, Matthew. "Education and the Right to Autonomy." M.A., University of Victoria, 2012.

Ryan, Gillespie, "Reason, Religion, and Postsecular Liberal-Democratic Epistemology," Philosophy \& Rhetoric Vol. 47 No. 1 (2014): 1-24.

Schneewind, J. B. The Invention of Autonomy: A History of Modern Moral Philosophy. Cambridge: Cambridge University Press, 1999.

Singh, L. et. al., "Back to Basics: A Bilingual Advantage in Infant Visual Habituation," Child Development Vol. 86 No. 1 (2015): 294-302.

Strauss, L. Jerusalem and Athens: Jewish Philosophy and the Crisis of Modernity. New York: State University of New York Press, 1997.

Tan, Charlene, "The Teaching of Religious Knowledge in a Plural Society: The Case for Singapore," International Review of Education / Internationale Zeitschrift Für Erziehungswissenschaft / Revue Internationale De L'Education Vol. 54 No. 2 (2008): 175-191.

Tan., Caroline, "Rationality and Autonomy from the Enlightenment and Islamic Perspectives," Journal of Beliefs \& Values Vol. 35 No. 3 (2014): 327-339.

Taylor, Robert S., "Kantian Personal Autonomy," Political Theory Vol. 33 No. 5 (2005): 602-628.

Thibert, Jeffrey Ryan. "Worldview Education: A Possibility for Autonomy-Facilitating Education in Islamic Schools." Ph.D, University of Illinois, 2012. 